\title{
SPECIES DIFFERENTIATION OF SLIPPER ORCHIDS USING COLOR IMAGE ANALYSIS
}

\author{
Ernesto Sanz ${ }^{1}$, Noreen von Cramon-Taubadel ${ }^{2} \&$ David L. Roberts 33,4 \\ ${ }^{1}$ Departamento de Biología, Facultad de Ciencias, Universidad Autónoma de Madrid, C/Darwin, 2, \\ E-28049 Madrid, Spain \\ ${ }^{2}$ Department of Anthropology, School of Anthropology and Conservation, University of Kent, \\ Marlowe Building, Canterbury, Kent CT2 7NR, U.K. \\ ${ }^{3}$ Durrell Institute of Conservation and Ecology, School of Anthropology and Conservation, \\ University of Kent, Marlowe Building, Canterbury, Kent CT2 7NR, U.K. \\ ${ }^{4}$ Corresponding author: d.l.roberts@kent.ac.uk
}

\begin{abstract}
A number of automated species recognition systems have been developed recently to aid nonprofessionals in the identification of taxa. These systems have primarily used geometric morphometric based techniques, however issues surround their wider applicability due to the need for homologous landmarks. Here we investigate the use of color to discriminate species using the two horticulturally important slipper orchid genera of Paphiopedilum and Phragmipedium as model systems. The ability to differentiate the various taxonomic groups varied, depending on the size of the group, diversity of colors within the group, and the background of the image. In this study the image analysis was conducted with images of single flowers of the species, however since flowers are ephemeral, flowering for a relatively short period of time, such analysis should be extended to vegetative parts, particularly as this is the form in which they are most often traded internationally.
\end{abstract}

RESUMEN. Una gran cantidad de sistemas de reconocimiento automático de especies se han desarrollado en los últimos años, como ayuda a aquellas personas que no son especialistas en la identificación de especies. Estos sistemas han utilizado sistemas de reconocimiento automático basados en geometría morfométrica, sin embargo existen límites debido a la necesidad de encontrar puntos de georreferenciación en los diferentes organismos. En este artículo investigamos el uso de los colores para diferenciar especies en los géneros Paphiopedilum y Phragmipedium, ambos con gran importancia en la horticultura. La capacidad de discriminación varía entre los grupos taxonómicos, dependiendo del tamaño del taxón, la variedad de colores entre las especies y el fondo de las imágenes. En este estudio el análisis de imágenes se ha llevado a cabo con fotografías de flores individuales. No obstante dado que las flores son órganos efímeros, en el futuro esta investigación incluirá partes vegetativas, ya que es en estado vegetativo la forma en la que se suele comerciar internacionalmente más a menudo.

Key words: digital, discrimination, Orchidaceae, Paphiopedilum, photograph, Phragmipedium

Introduction. The scientific community is facing a taxonomic crisis. Linnean shortfall, a euphemism for the hole in our knowledge of biodiversity, cannot be estimated to within an order of magnitude (May 1988). Faced with the vast number of species yet to be discovered, coupled with the diminishing training of new taxonomists (Hopkins \& Freckleton 2002) and accelerating extinction rates (Pimm et al. 2006), the task of cataloguing Earth's biodiversity is immense. Accurate species identification is key to meeting this challenge, however misidentification is an ever-present problem.
For some species, routine assessments, such as counting the dorsal spines of stickleback fish (Gasterosteidae), can result in accuracies as high as $95 \%$. For others more experience is required, and in some cases inconsistent identification can be over 40\% (MacLeod et al. 2010). To reduce such errors we rely on expert opinion for the verification of a taxon's identity. Border agencies are interested in identifying species controlled under CITES, agriculturalists in pest species, building developers in legally protected species, the horticultural industry in difference between new hybrids, as well as 
the amateur naturalist communities' general interest. Rapid and precise identifications are important for society as a whole. Computer-based automated species recognition has therefore been suggested as a potential technology to aid in the rapid identification of species, particularly taxa that form part of routine investigations (MacLeod et al. 2010).

Automated species recognition largely focused on using geometric morphometic-based techniques, such as the elliptic Fourier description and landmark analysis (MacLeod et al. 2010). The problem is that, at least for landmark analysis, they rely on homologous points. For example in face recognition (Shi et al. 2006), the tip of a nose may be considered homologous (in the sense of evolutionary origins, growth and development etc.) as that of another human, however the further we move away from the same species or taxon the more difficult it becomes to place the landmark (e.g. where would you place the same landmark on an insect or an orchid?). The issue surrounding homology of landmarks reduces their applicability, resulting in the proliferation of individual bespoke systems. Color has, however, only been used rarely within the field of species recognition (Das et al. 1999; Nilsback \& Zisserman 2008). Here we investigate whether orchids can be differentiated based on color. Specifically we look the slipper orchid genera, Paphiopedilum and Phragmipedium, due to their importance within the orchid horticultural industry and the fact that, being on Appendix I of the Convention on International Trade in Endangered Species, they are of particular concern to inspectors at border posts.

Material and methods. A checklist of the two slipper orchid genera, Paphiopedilum and Phragmipedium, was constructed using the online World Checklist of Selected Flowering Plant Families (http://apps.kew. org/wcsp), and following the sectional delimitations of Cribb (1998; pers. comm.) and Pridegon et al. (1999). Digital images were then identified on the internet using a search engine (http://www.google. com/). Specifically we looked for images of species from the two genera that had approximately a black background, showed a single flower facing forward and minimal other parts of the plant. These images were then downloaded and a database was collated in Microsoft Excel. The downloaded images were analyzed using the online Image Color Summarizer v0.5 (http://mkweb.bcgsc.ca/color_summarizer/). For each image, a text file was generated containing the pixel frequencies for red (R), blue (B), green (G), hue $(\mathrm{H})$, saturation (S) and value (V). The setting 'extreme' precision control was used.

Factor analysis was performed to decompose the resultant variables obtained from the image analysis into principal components. Components which explained at least $1 \%$ of the total variance were extracted and used as input variables for a multivariate Discriminant Function Analysis (DFA). DFA was used in order to assess the extent to which the pixel frequency data could be employed to correctly classify individual specimens back to correct group. The analysis was conducted for all species, grouping by subgenus (in the case of Paphiopedilum) and by taxonomic section (in the case of Phragmipedium and each subgenus of Paphiopedilum). From these analyses we focused on the leave-one-out classification, (a) the percentage original grouped cases correctly classified, which determines if the images were properly named, and (b) the percentage cross-validated grouped cases correctly classified, that determines if it is possible to recognize the image as it was labeled. Analyses to determine the potential impact of background color on discrimination were also conducted by cropping the image and placing it on a white background. All statistical analyses were performed using SPSS 19.0.

Results. From a search of the internet, 703 images representing 84 species of Paphiopedilum and 214 images representing 25 species of Phragmipedium were acquired (Tables 1 and 2). This represents 96\% coverage of both genera.

Paphiopedilum. - Cross-validation within sections and subgenera illustrated that some species were easier to distinguish than others (Table 3). For example, Paphiopedilum glaucophyllum and P. liemianum have broadly similar colors and therefore even within an analysis of species just from the section Cochlopetalum, only $18.2 \%$ of images of $P$. liemianum could be assigned to correct species and in the case of P. glaucophyllum no images could be placed within the species. As mentioned this could be due to the similarity in color of the two species and others 
TABle 1. A list of species from the genus Paphiopedilum, taxonomy and the number of images used within the study.

\begin{tabular}{|c|c|c|c|}
\hline Species & Subgenus & Section & No. images \\
\hline P. acmodontum M.W.Wood & Paphiopedilum & Barbata & 3 \\
\hline P. adductum Asher & Paphiopedilum & Coryopedilum & 4 \\
\hline P. appletonianum (Gower) Rolfe & Paphiopedilum & Barbata & 8 \\
\hline P. aranianum Petchl. & Paphiopedilum & Paradalopetalum & 0 \\
\hline$P$. argus (Rchb.f.) Stein & Paphiopedilum & Barbata & 11 \\
\hline$P$. armeniacum S.C.Chen \& F.Y.Liu & Parvisepalum & Parvisepalum & 12 \\
\hline P. barbatum (Lindl.) Pfitzer & Paphiopedilum & Barbata & 13 \\
\hline P. barbigerum Tang \& F.T.Wang & Paphiopedilum & Paphiopedilum & 5 \\
\hline P. bellatulum (Rchb.f.) Stein & Brachypetalum & Brachypetalum & 6 \\
\hline P. bougainvilleanum Fowlie & Paphiopedilum & Barbata & 7 \\
\hline P. bullenianum (Rchb.f.) Pfitzer, & Paphiopedilum & Barbata & 5 \\
\hline P. callosum (Rchb.f.) Stein, & Paphiopedilum & Barbata & 10 \\
\hline P. canhii Aver. \& O.Gruss & Paphiopedilum & Barbata & 3 \\
\hline P. charlesworthii (Rolfe) Pfitzer & Paphiopedilum & Paphiopedilum & 12 \\
\hline P. ciliolare (Rchb.f.) Stein & Paphiopedilum & Barbata & 9 \\
\hline P. concolor (Lindl. ex Bateman) Pfitzer & Brachypetalum & Brachypetalum & 3 \\
\hline P. dayanum (Lindl.) Stein & Paphiopedilum & Barbata & 11 \\
\hline P. delenatii Guillaumin & Parvisepalum & Parvisepalum & 10 \\
\hline P. dianthum Tang \& F.T.Wang & Paphiopedilum & Paradalopetalum & 4 \\
\hline P. druryi (Bedd.) Stein & Paphiopedilum & Paphiopedilum & 12 \\
\hline P. emersonii Koop. \& P.J.Cribb & Parvisepalum & Parvisepalum & 13 \\
\hline P. exul (Ridl.) Rolfe & Paphiopedilum & Paphiopedilum & 4 \\
\hline$P$. fairrieanum (Lindl.) Stein & Paphiopedilum & Paphiopedilum & 16 \\
\hline P. fowliei Birk & Paphiopedilum & Barbata & 12 \\
\hline P. gigantifolium Braem & Paphiopedilum & Coryopedilum & 2 \\
\hline P. glanduliferum (Blume) Stein & Paphiopedilum & Coryopedilum & 4 \\
\hline P. glaucophyllum J.J.Sm & Paphiopedilum & Cochlopetalum & 7 \\
\hline P. godefroyae (God.-Leb.) Stein & Brachypetalum & Brachypetalum & 11 \\
\hline$P$ gratrixianum Rolfe & Paphiopedilum & Paphiopedilum & 10 \\
\hline P. guangdongense Z.J.Liu \& L.J.Chen & Paphiopedilum & Paphiopedilum & 0 \\
\hline P. hangianum Perner \& O.Gruss & Parvisepalum & Parvisepalum & 8 \\
\hline P. haynaldianum (Rchb.f.) Stein & Paphiopedilum & Paradalopetalum & 5 \\
\hline P. helenae Aver & Paphiopedilum & Paphiopedilum & 12 \\
\hline P. hennisianum (M.W.Wood) Fowlie & Paphiopedilum & Barbata & 6 \\
\hline P. henryanum Braem & Paphiopedilum & Paphiopedilum & 9 \\
\hline P. hirsutissimum (Lindl. ex Hook.) Stein & Paphiopedilum & Paphiopedilum & 9 \\
\hline P. hookerae (Rchb.f.) Stein & Paphiopedilum & Barbata & 16 \\
\hline P. inamorii P.J.Cribb \& A.L.Lamb & Paphiopedilum & Barbata & 1 \\
\hline
\end{tabular}


Table 1. Continues.

\begin{tabular}{|c|c|c|c|}
\hline Species & Subgenus & Section & No. images \\
\hline P. insigne (Wall. ex Lindl.) Pfitzer & Paphiopedilum & Paphiopedilum & 13 \\
\hline P. javanicum (Reinw. ex Lindl.) Pfitzer & Paphiopedilum & Barbata & 8 \\
\hline P. kolopakingii Fowlie & Paphiopedilum & Coryopedilum & 1 \\
\hline P. lawrenceanum (Rchb.f.) Pfitzer & Paphiopedilum & Barbata & 12 \\
\hline P. liemianum (Fowlie) K.Karas. \& K.Saito & Paphiopedilum & Cochlopetalum & 11 \\
\hline P. lowii (Lindl.) Stein & Paphiopedilum & Paradalopetalum & 6 \\
\hline P. malipoense S.C.Chen \& Z.H.Tsi & Parvisepalum & Parvisepalum & 20 \\
\hline P. mastersianum (Rchb.f.) Stein & Paphiopedilum & Barbata & 11 \\
\hline P. micranthum Tang \& F.T.Wang & Parvisepalum & Parvisepalum & 18 \\
\hline P. niveum (Rchb.f.) Stein & Brachypetalum & Brachypetalum & 17 \\
\hline P. ooii Koop & Paphiopedilum & Coryopedilum & 1 \\
\hline P. papuanum (Ridl. ex Rendle) L.O.Williams & Paphiopedilum & Barbata & 12 \\
\hline P. parishii (Rchb.f.) Stein & Paphiopedilum & Paradalopetalum & 4 \\
\hline P. parnatanum Cavestro & Paphiopedilum & Barbata & 6 \\
\hline P. philippinense (Rchb.f.) Stein & Paphiopedilum & Coryopedilum & 2 \\
\hline P. platyphyllum T.Yukawa & Paphiopedilum & Coryopedilum & 1 \\
\hline P. primulinum M.W.Wood \& P.Taylor & Paphiopedilum & Cochlopetalum & 9 \\
\hline P. purpuratum (Lindl.) Stein & Paphiopedilum & Barbata & 7 \\
\hline P. randsii Fowlie & Paphiopedilum & Coryopedilum & 4 \\
\hline P. rothschildianum (Rchb.f.) Stein & Paphiopedilum & Coryopedilum & 2 \\
\hline P. sanderianum (Rchb.f.) Stein & Paphiopedilum & Coryopedilum & 1 \\
\hline P. sangii Braem & Paphiopedilum & Barbata & 12 \\
\hline P. schoseri Braem \& H.Mohr & Paphiopedilum & Barbata & 9 \\
\hline P. spicerianum (Rchb.f.) Pfitzer & Paphiopedilum & Paphiopedilum & 14 \\
\hline P. stonei (Hook.) Stein & Paphiopedilum & Coryopedilum & 4 \\
\hline P. sugiyamanum Cavestro & Paphiopedilum & Barbata & 4 \\
\hline P. sukhakulii Schoser \& Senghas & Paphiopedilum & Barbata & 14 \\
\hline P. supardii Braem \& Löb & Paphiopedilum & Coryopedilum & 2 \\
\hline P. superbiens (Rchb.f.) Stein & Paphiopedilum & Barbata & 14 \\
\hline P. thaianum lamwir & Brachypetalum & Brachypetalum & 16 \\
\hline P. tigrinum Koop. \& N.Haseg & Paphiopedilum & Paphiopedilum & 9 \\
\hline P. tonsum (Rchb.f.) Stein & Paphiopedilum & Barbata & 19 \\
\hline P. tranlienianum O.Gruss \& Perner & Paphiopedilum & Paphiopedilum & 7 \\
\hline P. urbanianum Fowlie & Paphiopedilum & Barbata & 15 \\
\hline P. venustum (Wall. ex Sims) Pfitzer, Jahrb & Paphiopedilum & Barbata & 16 \\
\hline P. victoria-mariae (Sander ex Mast.) Rolfe & Paphiopedilum & Cochlopetalum & 6 \\
\hline P. victoria-regina (Sander) M.W.Wood & Paphiopedilum & Cochlopetalum & 4 \\
\hline P. vietnamense O.Gruss \& Perner & Parvisepalum & Parvisepalum & 18 \\
\hline
\end{tabular}


TABle 1. Continues.

\begin{tabular}{l|l|l|c}
\hline Species & Subgenus & Section & No. images \\
\hline P. villosum (Lindl.) Stein & Paphiopedilum & Paphiopedilum & 11 \\
\hline P. violascens Schltr. & Paphiopedilum & Barbata & 17 \\
\hline P. wardii Summerh. & Paphiopedilum & Barbata & 18 \\
\hline P. wenshanense Z.J.Liu \& J.Yong Zhang & Brachypetalum & Brachypetalum & 4 \\
\hline P. wentworthianum Schoser \& Fowlie & Paphiopedilum & Barbata & 6 \\
\hline P. wilhelminae L.O.Williams & Paphiopedilum & Coryopedilum & 3 \\
\hline
\end{tabular}

a $P$. cornuatum Z.J.Liu, O. Gruss \& L.J. Chen is excluded as it is considered to be a variety of $P$. villosum (Cribb pers. comm.). P. qingyongii Z.J.Liu \& L.J.Chen is excluded as it is believed to be a natural hybrid (Averyanov pers. comm.)

within the section, however incorrect identification of images on the internet in the first place could also be a confounding factor. Conversely in the subgenus Parvisepalum, P. armeniacum was correctly assigned to the species $61.5 \%$ of the time, while $P$. malipoense was correctly identified $70.0 \%$ of the time owing to the distinctive color of this species, relative to the diversity of colors within this subgenus. Subgenus Parvisepalum with seven species was found to have the highest crossvalidation at $52.0 \%$, while for the section Barbata, with 31 species, cross-validation was $15.5 \%$; although this was not the lowest (Table 3). Moving to a higher taxonomic level, section cross-validation was $39.5 \%$. When the genus was analyzed as a whole, only two of the 84 species of Paphiopedilum could be identified at least two-thirds of the time; $P$. wentworthianum (66.7\%), and P. dianthum (75.0\%).

Phragmipedium. - Similar to the situation seen in the genus Paphiopedilum, there was considerable variation in the ability to correctly identify species in the genus Phragmipedium (Table 4). Species such as P. caricinum from the section Himantopetalum had a low percentage of cross-validation (12.5\%), with P. longifolium from the section Lorifolia being the lowest $(0 \%)$. At the opposite end of the spectrum $P$. lindenii from the section Phragmipedium had 100\% cross-validation. The section Platypetalum showed the highest cross-validation at $53.3 \%$ due to the low number of species in this section (only 2 species), whereas the section Lorifolia only had $18.9 \%$ crossvalidation.

In Phragmipedium when all the species were analyzed by grouping them by section, section identification had a high cross-validation (46.6\%), only slightly below that seen for the section Platypetalum $(53.3 \%)$. When looking at the genus as a whole, three of the 25 species analyzed had cross-validation percentages above $60 \%$; $P$. bessae with $61.1 \%, P$. schlimii with $73.7 \%$ and $P$. tetlzaffianum with $75 \%$; being mistaken with only one other species in the case of $P$. bessae and P. tetlzaffianum, but with five others in the case of $P$. schlimii, all of them having an equal percentage of cross-validation.

Image manipulation. - When images were manipulated in an attempt to control the background color variation mixed results were seen (Table 5). For subgenus Parvisepalum and section Paphiopedilum substantial increases in the ability to differentiate species was seen (52.0 to $67.7 \%$ and 24.6 to $47.8 \%$ respectively), however for subgenus Brachypetalum and section Cochlopetalum differentiation of species decreased (38.6 to $15.5 \%$ and 24.3 to $18.9 \%$ respectively).

Discussion. Within five years of being first described to science, Paphiopedilum vietnamense was declared Extinct in the Wild due to over-collecting for the horticultural trade (Averyanov et al. 2003). Those involved in CITES, particularly within the EU and USA, were quick to identify trade in this species, however as a result the species started being traded as the vinicolor form of the more widely and legally available $P$. delenatii (anon. pers. comm.). These species are easy to tell apart, but only with knowledge and training; key distinguishing characters are in the staminode and leaves (Averyanov, pers. comm.).

In this study, color image analysis was used to determine if it is a potentially useful tool for differentiating species. Based on the analysis of over 
TABle 2. A list of species from the genus Phragmipedium, taxonomy and the number of images used within the study.

\begin{tabular}{|c|c|c|}
\hline Species & Section & No. images \\
\hline P. andreettae P.J.Cribb \& Pupulin & Micropetalum & 8 \\
\hline P. besseae Dodson \& J.Kuhn & Micropetalum & 19 \\
\hline P. boissierianum (Rchb.f. \& Warsz.) Rolfe & Lorifolium & 19 \\
\hline P. brasiliense Quené \& O.Gruss & Lorifolium & 5 \\
\hline P. caricinum (Lindl. \& Paxton) Rolfe & Himantopetalum & 7 \\
\hline P. caudatum (Lindl.) Rolfe & Phragmipedium & 8 \\
\hline P. christiansenianum O.Gruss \& Roeth & Himantopetalum & 5 \\
\hline P. exstaminodium Castaño, Hágsater \& E.Aguirre & Phragmipedium & 5 \\
\hline P. fischeri Braem \& H.Mohr & Micropetalum & 8 \\
\hline P. hartwegii (Rchb.f.) Pfitzer & Lorifolium & 1 \\
\hline P. hirtzii Dodson & Lorifolium & 5 \\
\hline P. klotzschianum (Rchb.f.) Rolfe & Himantopetalum & 4 \\
\hline P. kovachii J.T.Atwood & Schluckebieria & 9 \\
\hline P. lindenii (Lindl.) Dressler \& N.H.Williams & Phragmipedium & 3 \\
\hline P. lindleyanum (M.R.Schomb. ex Lindl.) Rolfe & Platypetalum & 7 \\
\hline P. longifolium (Warsz. \& Rchb.f.) Rolfe & Lorifolium & 14 \\
\hline P. manzurii W.E.Higgins \& Viveros & Micropetalum & 1 \\
\hline P. pearcei (Rchb.f.) Rauh \& Senghas & Himantopetalum & 13 \\
\hline$P$. reticulatum (Rchb.f.) Schltr. & Lorifolium & 2 \\
\hline P. richteri Roeth \& O.Gruss & Himantopetalum & 15 \\
\hline P. sargentianum (Rolfe) Rolfe & Platypetalum & 6 \\
\hline P. schlimii (Linden ex Rchb.f.) Rolfe & Micropetalum & 19 \\
\hline P. tetzlaffianum O.Gruss & Himantopetalum & 4 \\
\hline P. vittatum (Vell.) Rolfe & Lorifolium & 4 \\
\hline P. warszewiczianum (Rchb.f.) Schltr. & Phragmipedium & 7 \\
\hline P. warscewiczii (Rchb.f.) Christenson & Phragmipedium & 0 \\
\hline
\end{tabular}

900 images from 109 species of slipper orchids, the results suggest that color image analysis does have the potential to differentiate certain species, however only a few can be differentiated with any degree of accuracy $(>66.6 \%)$.

As one may expect, as the number of species decrease the ability to differentiate species increases, coupled with this is the diversity of major colors within a taxon; as the color to species ratio increase so does species differentiation. This therefore begs the question why would such as system be useful if it can only differentiate species that are obviously different? Paphiopedilum armeniacum and P. malipoense are obviously different from species within the section
Parvisepalum, certainly to an orchid taxonomist or a grower with knowledge of orchids. However, correct identification requires a priori knowledge in the first instant to differentiate them from other species. Even with detailed knowledge, the system classification is not $100 \%$ accurate. Our analyses suggest that using image analyses reduced the likelihood of errors; rather than looking through all $80+$ species of Paphiopedilum one may only need to have a look at five or ten species. Sixty-seven percent of species from the genus Paphiopedilum were confused with only eight or fewer other species, thereby reducing the options to less than $10 \%$ of the original number of species. By doing so this reduces the time spent by those involved in trying 
TABLE 3. Percentage of specimens correctly classified into original group and the cross-validated grouping results for specimens in the genus Paphiopedilum.

\begin{tabular}{|c|c|c|c|c|c|}
\hline Subgenus & Section & No. spp. & No. images & $\begin{array}{c}\text { Original } \\
\text { grouped (\%) }\end{array}$ & $\begin{array}{c}\text { Cross-validated } \\
\text { grouped (\%) }\end{array}$ \\
\hline Parvisepalum & Parvisepalum & 7 & 100 & 98.0 & 52.0 \\
\hline Brachypetalum & Brachypetalum & 6 & 57 & 100.0 & 38.6 \\
\hline Paphiopedilum & Coryopedilum & 13 & 31 & 100.0 & 9.7 \\
\hline Paphiopedilum & Paradalopetalum & 4 & 19 & 100.0 & 36.8 \\
\hline Paphiopedilum & Cochlopetalum & 5 & 37 & 97.4 & 24.3 \\
\hline Paphiopedilum & Paphiopedilum & 14 & 143 & 89.4 & 24.6 \\
\hline Paphiopedilum & Barbata & 31 & 316 & 71.5 & 15.5 \\
\hline All (sections) ${ }_{a}$ & All & 7 (sections) & 703 & 66.4 & 39.5 \\
\hline All (species) $)_{b}$ & All & 84 & 703 & 31.9 & 8.3 \\
\hline
\end{tabular}

Analysis conducted using all species grouped by ${ }_{\mathrm{a}}$ sections and bspecies.

to identify individuals to the species level who may not have same in-depth knowledge, such as border customs officials, and thereby reducing the number of enquiries that pass through to the small number of specialist taxonomists.

Several factors are likely to impact on any system to differentiate species, such as orientation of the subject, quality and settings of the camera used to take the image, distance from subject, the part of the subject photographed (e.g. single flower, inflorescence or whole plant) and background of the subject. In this study we tried to control some of these by using approximately forward facing images of single flowers on a black background.
Further, we attempted to reduce the impact of the background with mixed consequences. In some cases this increased the ability to differentiate species, while in others it reduced the ability to differentiate. What was interesting is that it increased accuracy in those taxonomic groups that were generally singled flowered on tall inflorescences that held the flower away from the vegetative parts, while controlling the background of the flower decreased accuracy in those species that where multiple flowered and/or held the flower/s close to the vegetative parts. This illustrates how the background of the image can impact positively on species identification, and may not necessarily be a source that can precipitate error.

TABLE 4. Percentage of specimens correctly classified into original group and the cross-validated grouping results for specimens in the genus Phargmipedium.

\begin{tabular}{l|c|c|c|c}
\hline Section & No. spp. & No. images & Original & Cross-validated grouped \\
grouped (\%)
\end{tabular}

Analysis conducted using all species grouped by ${ }_{\mathrm{a}}$ sections and bspecies. 
TABLE 5. Results of the Discriminant Function Analysis comparing the manipulated images against the unaltered images of the subgenera Brachypetalum and Parvisepalum and the sections Cochlopetalum and Paphiopedilum of the subgenus Paphiopedilum.

\begin{tabular}{l|l|l|l}
\hline Taxonomic Groups & Discrimination & Unaltered & Altered \\
\hline \multirow{2}{*}{ Subgenus Brachypetalum } & Original grouped (\%) & 100.0 & 100.0 \\
\cline { 2 - 4 } & Cross-validated grouped (\%) & 38.6 & 15.5 \\
\hline \multirow{2}{*}{ Subgenus Parvisepalum } & Original grouped (\%) & 98.0 & 100.0 \\
\cline { 2 - 4 } & Cross-validated grouped (\%) & 52.0 & 67.7 \\
\hline \multirow{2}{*}{ Section Cochlopetalum } & Original grouped (\%) & 97.4 & 100.0 \\
\cline { 2 - 4 } Section Paphiopedilum & Cross-validated grouped (\%) & 24.3 & 18.9 \\
\hline \multirow{2}{*}{} & Original grouped (\%) & 89.4 & 95.6 \\
\cline { 2 - 4 } & Cross-validated grouped (\%) & 24.6 & 47.8 \\
\hline
\end{tabular}

Increased accuracy may be achieved through the use or addition of shape analysis, and for the majority of species recognition systems this is what it is based on (MacLeod et al. 2010). Phragmipedium exstaminodium and $P$. warszwewiczianum are difficult to differentiate based on color but are quite obviously different when one looks at the shape of the staminode. Further it is possible to differentiate most species of Phragmipedium using geometric morphometrics based only on the shape of the staminode (unpublished data). However, as mentioned in the introduction, the problem arises when one tries to expand the system from a small group of morphologically similar species, due to homology. In the case of staminode morphology in Phragmipedium, it is unlikely to have wider application beyond the Cypripedioideae. Further, such taxonomically focused tools for automating species recognition are also only likely to be developed for those species that are of particular commercial concern, e.g. timber and ivory. This also includes DNA-based technologies, where although costs are continuing to fall, within and between species identification is only economically practical for commercially important species and items that have DNA to start with (e.g. not treated items such as leathers or objects such as photographs). If automated species recognition systems are to be developed for taxonomic groups that are not commercially important, and/or taxonomic groups that are extremely species rich (as is the case for orchids), then more generalizable methods such as color image analyzes are needed. Further work is required into image analyzes systems to understand the impact on identification of confounding factors such as the environment in which they are grown (e.g. temperature, fertilizer regime), photographic system (e.g. camera specific optics, image resolution) and expansion to other taxa including hybrids and color forms.

Returning to the case of Paphiopedilum vietnamense, which is similar to $P$. delenatii, but can, as mentioned earlier, be easily distinguished on the basis of their leaves (Averyanov, pers. comm.; Cribb, pers. comm.). A logical progression to this line of research would be to investigate species differentiation using color image analyzes on vegetative parts of the plant. This is the form in which orchids are more often traded and therefore customs officials are likely to be confronted with.

ACKNOWLEDGEMENTs. The authors would like to thank Drs. Averyanov and Cribb for discussions on identification and classification of slipper orchids. Two anonymous reviewers provided helpful feedback. ES was funded through an EU Erasmus placement grant.

\section{Literature Cited}

Averyanov, L., P. Cribb, P.K. Loc \& M.H. Hiep. 2003. Slipper Orchids of Vietnam. Royal Botanic Gardens, Kew, UK.

Cribb, P. 1998. The Genus Paphiopedilum, $2^{\text {nd }}$ Ed. Natural History Publications (Borneo), Malaysia.

Das, M., R. Manmatha \& E.M. Riseman. 1999. Indexing flower patent images using domain knowledge. IEEE Intell. Syst. 14: 24-33.

Hopkins, G.W. \& R.P. Freckleton. 2002. Declines in the 
numbers of amateur and professional taxonomists: implications for conservation. Anim. Conserv. 5 : 245-249.

MacLeod N., B. Mark \& P. Culverhouse. 2010. Time to automate identification. Nature 467: 154-155.

May, R.M. 1988. How many species are there on Earth? Science 241: 1441-1449.

McGough, H.N., D. L. Roberts, C. Brodie \& J. Kowalczyk. 2006. CITES and Slipper Orchids. An introduction to slipper orchids covered by the Convention on International Trade in Endangered Species. The Board of Trustees, Royal Botanic Gardens, Kew, UK.

Nilsback, M.-E. \& A. Zisserman. 2008. Automated flower classification over a large number of classes.
Proceedings of the Indian Conference on Computer Vision, Graphics and Image Processing 6: 722-729.

Pimm, S., P. Raven, A. Peterson, C. H. Şekercioğlu \& P. R. Ehrlich. 2006. Human Impacts on the rates of recent, present, and future bird extinctions. P. Natl. Acad. Sci. USA 103: 10941-10946.

Pridgeon, A. M., P. J. Cribb, M. W. Chase \& F. Rasmussen (eds.). 1999. Genera Orchidacearum, Vol 1: Apostasioideae and Cypripedioideae. Oxford University Press, UK

Shi, J., A. Samal \& D. Marx. 2006. How effective are landmarks and their geometry for face recognition? Comput. Vis. Image Und. 102: 117-133. 